\title{
Morphogenesis of postacrosomal cytoplasm in the spermatid head. Experimental study of hypophysectomized and testosterone-injected rams
}

\author{
par J. L. COURTENS
}

Station de Physiologie de la Reproduction, I. N. R. A., Nouzilly, 37380 Monnaie, France.

\begin{abstract}
Summary. A comparison of the ultrastructural aspects of step 12 spermatids from both normal and testosterone-supplemented, hypophysectomized rams (for 15 or 20 days) indicated a hierarchy of the morphogenetic factors implicated in postacrosomal cytoplasm differentiation. The first factor was a modification of the nuclear nucleoprotein composition, followed by modifications in the structure of the nuclear envelope and then by a backward displacement of the postnuclear band and associated perinuclear ring. The postnuclear band was directly involved in the close apposition of the plasma membrane and the cytoplasmic organelles of the spermatid postacrosomal region.
\end{abstract}

\section{Introduction.}

In a great variety of species, the postacrosomal cytoplasm has been described at the ultrastructural level as a differentiated part of the sperm head (Fawcett, 1970 ; Jones, 1970, 1971 ; Franklin et al., 1970 ; Gordon, 1972 ; Fléchon, 1975 ; Bedford, 1974 ; Bustos-Obregon et al., 1975). Its formation during spermiogenesis has received incomplete attention (Sandoz, 1970 ; Lalli, 1972), and therefore the morphogenetic factors influencing its differentiation are not fully understood (Fawcett ef al., 1971). In a preceding paper we demonstrated that the differentiation of the organelles of that region occurred during step 12 of normal ram spermiogenesis, following removal of lysine-rich proteins from the nucleus (Courtens and Loir, 1975b). The present investigation in ram is an attempt to demonstrate that the removal of these nuclear proteins is the main factor involved in the morphogenesis of postacrosomal cytoplasm. This demonstration is based on the comparison of spermatid morphogenesis in both the normal and testosterone-supplemented, hypophysectomized ram.

\section{Material and methods.}

1. Animals. - Immediately after hypophysectomy $\left(\mathrm{H}^{-}\right), 6$ rams were IM injected twice daily with $0.25 \mathrm{~g}$ of testosterone for 15 or 20 days during the breeding season, 


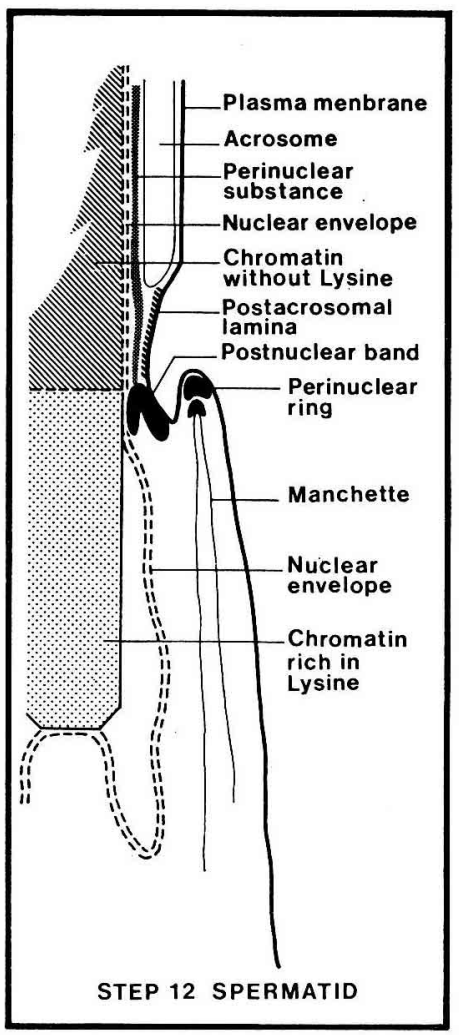

FIG. 1 and 2. - Normal step 12 spermatid.

According to Courtens and Loir (1975) the lysine-rich nuclear proteins are lost as the nuclear envelope (ne) is applied against the chromatin $(N)$; the postnuclear band $(\mathrm{pb})$ slips backwards between both the nuclear envelope and the plasma membrane $(\mathrm{m})$; the perinuclear substance, present under the acrosome, develops backwards; the postacrosomal lamina (L) appears close to the plasma membrane ; the perinuclear ring $(\mathrm{pr})$ and associated manchette $(\mathrm{mt})$ slip backwards.

FIG. 1. - Schematic drawing.

FIG. 2. - Observed pattern in early step 12 ( $\times 19500$ ).

FIG. 3, 4 and 5. - Abnormal differentiation of step 12-13 spermatids.

FIG. 3. - End of step $12(\times 32000)$. The perinuclear ring $(\mathrm{pr})$ attached to the postnuclear band $(\mathrm{pb})$ with the membranous ring $(R)$ is in distal position. The nuclear envelope (ne) is closely applied against the nucleus $(N)$. Material of the postacrosomal lamina $(L)$ is located in the cytoplasm far away from the plasma membrane $(M)$.

FIG. 4. - Mid-step 12 ( $\times 17500)$. The perinuclear ring (pr), not attached to the postnuclear band $(\mathrm{pb})$ by the membranous ring $(R)$, remains in an equatorial position while the postnuclear band slips backwards along the nuclear envelope.

FIG. 5. - Step $13(\times 19000)$. The postnuclear band $(\mathrm{pb})$ is in distal position ; the postacrosomal lamina (L) present in the cytoplasm is not close to the plasma membrane $(\mathrm{m})$. The manchefte and the perinuclear ring (pr) have not migrated backwards and their abnormal presence is already noted in the step 13 spermatid. Cytoplasmic organelles such as mitochondria (mi) are not in normal position. The Sertoli mantle (Ser) is turned back. The membranous ring (R) remains aftached to the perinuclear ring. 
(2) -

$x^{2}$

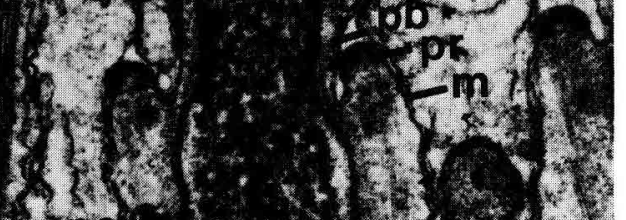

Toe

\section{(s)}

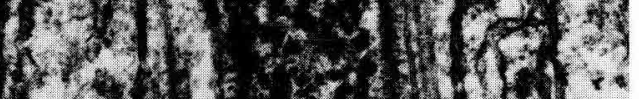

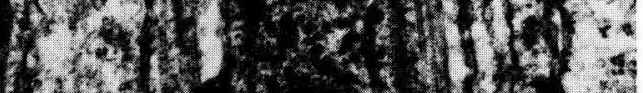

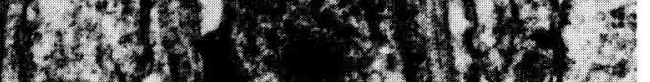

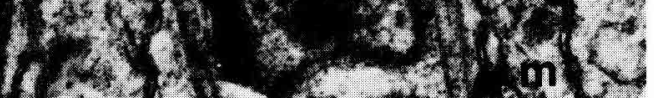
$f\left(2,4-2 x^{2}\right.$ $\left.8(12)^{2}\right)$

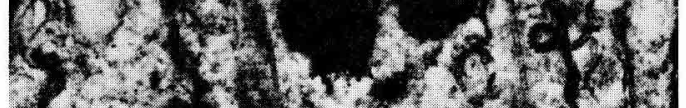

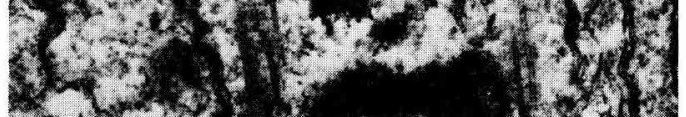

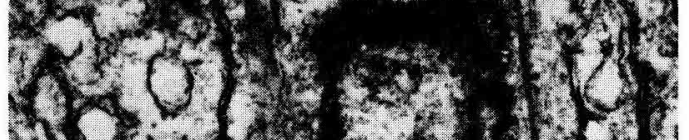
GP 4 , 5 ,

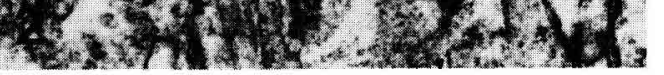

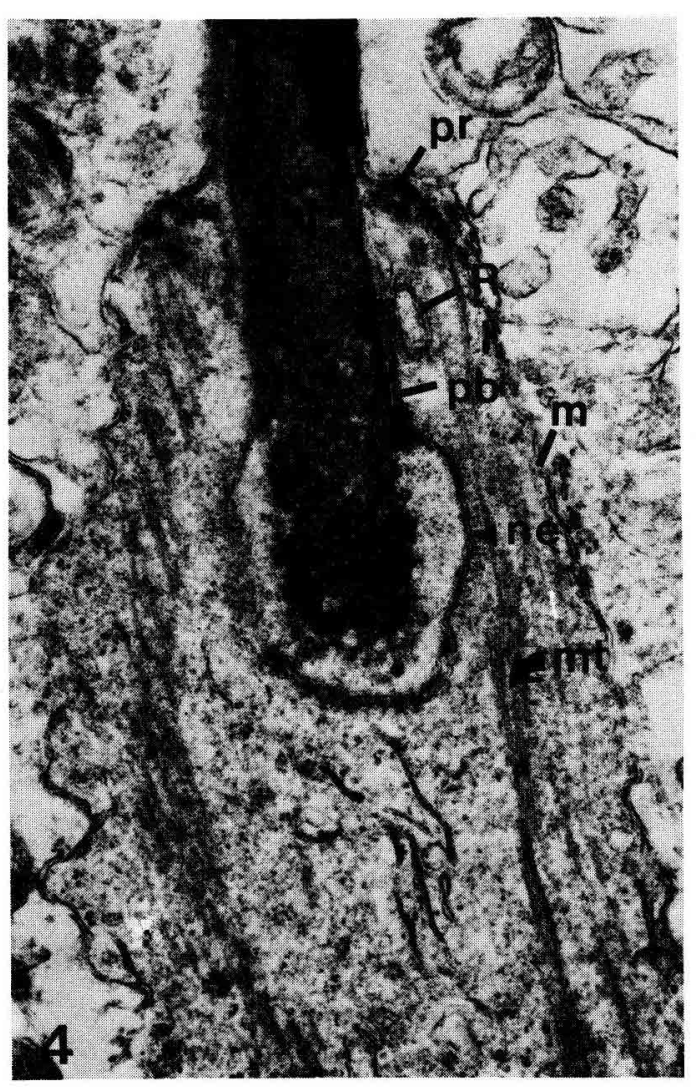

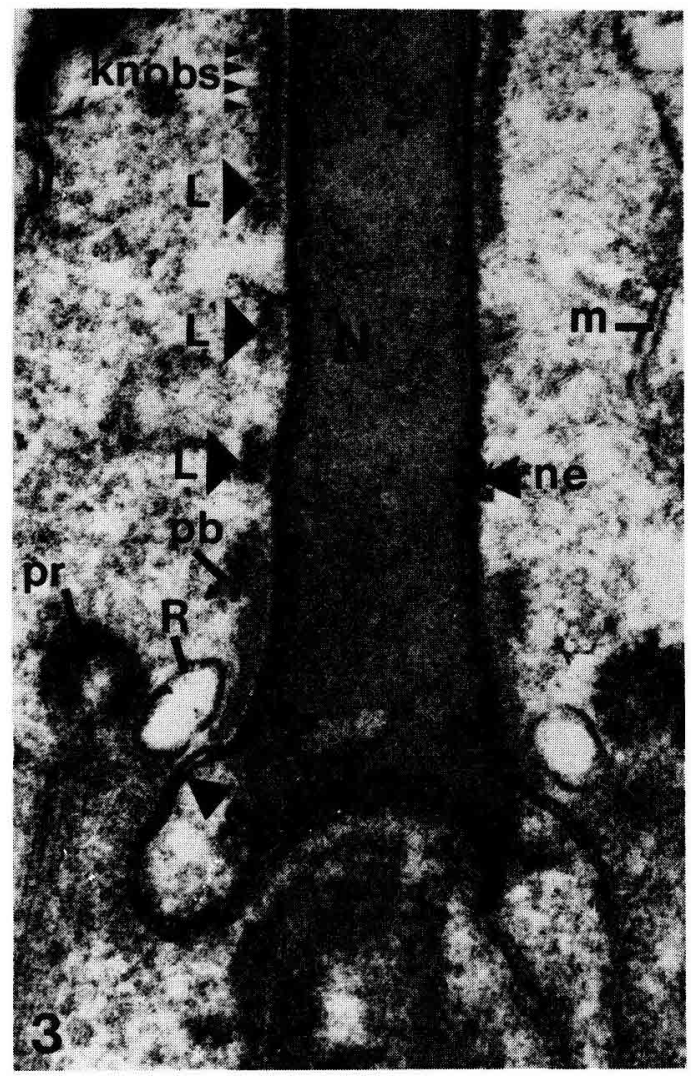

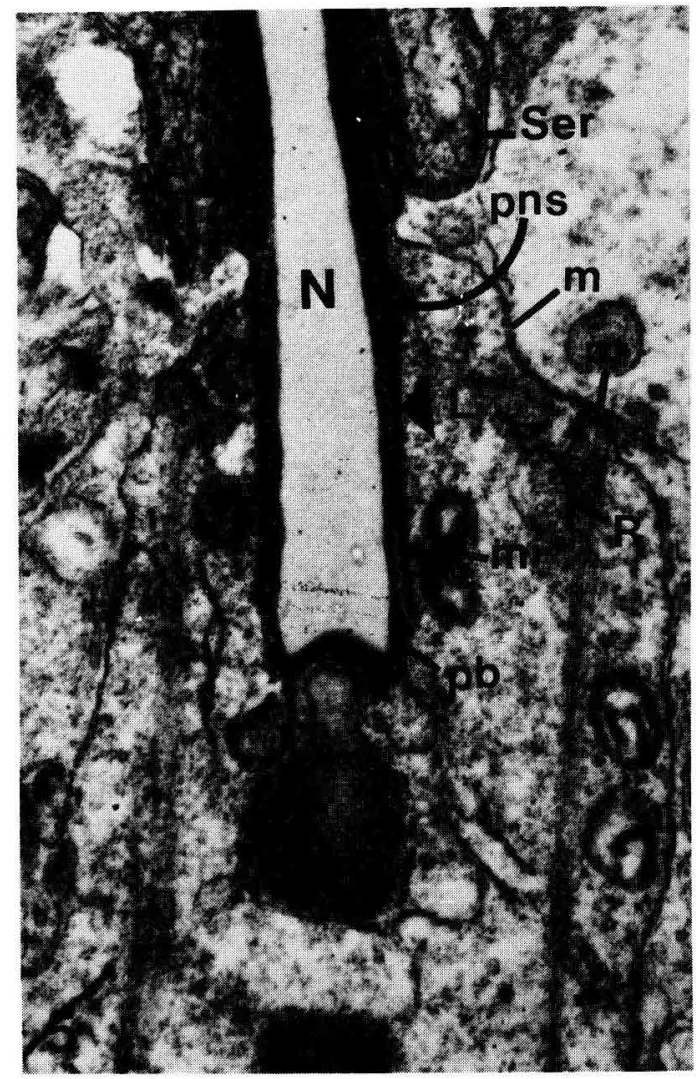


according to Monet-Kuntz ef al. (1976). These animals, as well as control rams injected with olive oil, were castrated by surgery under general anesthesia following the last injection.

2. Electron microscopy. - Small pieces of testis were fixed for 4 hrs with 4 p. 100 glutaraldehyde in $0.1 \mathrm{M}, \mathrm{pH} 7.4$ phosphate buffer. Following a rinse in the same buffer $(0.2 \mathrm{M})$, they were post-fixed with 2 p. 100 osmium tetroxyde in $0.2 \mathrm{M}$ phosphate buffer for 2 hrs. Ultrathin sections of epon-embedded material were stained with uranyl acetate and lead citrate. Some pieces were processed according to Courtens and Loir (1975a) for visualization of lysine residues. The steps of spermiogenesis were evaluated from the descriptions of Clermont and Leblond (1955) and Courtens (1978).

\section{Results.}

\section{A. Control rams.}

The differentiation of the postacrosomal cytoplasm in normal ram has been described in detail elsewhere (Courtens and Loir, 1975b). The main characteristics of this differentiation found in the present control animals, are summarized in figures 1 and 2 .

B. Abnormal differentiation of postacrosomal cytoplasm in testosterone-supplemented hypophysectomized rams.

1 to 5 p. 100 of the step 12 spermatids of these animals showed abnormal differentiation of the postacrosomal cytoplasm in front of the nucleus, which had normally lost its lysine-rich proteins. Most of the imperfect cells showed the following typical defective pattern :

a) the plasma membrane was detached from the posterior part of the acrosomal region (figs $3,4,5$ ) ;

b) the perinuclear ring was in most cases, but not all (fig. 4), attached to the postnuclear band by a membranous ring forming a tore encircling the nucleus (fig. 3 ) ;

c) the perinuclear ring-membranous tube-posfnuclear band unit had slipped backwards along the nuclear envelope during step 12 (fig. 3) ;

d) the perinuclear substance normally appeared along the nuclear envelope (figs 3-5) ;

e) the postacrosomal lamina appearing in the cytoplasm, far from the plasma membrane, was always covered with regularly-spaced knobs facing the external part of the cell (figs 3 and 5);

f) as the plasma membrane was not linked to the nuclear envelope by means of the postnuclear band, it ensued that the cytoplasmic organelles (i. e. mitochondria) did not assume a normal position in the posterior cytoplasm (fig. 5) ;

g) in most cases the microfibrillar Sertoli cell mantle normally developed backwards in front of portions of the spermatid plasma membrane situated far from the nucleus. In a few cases, the Sertoli mantle was turned back and did not cover the spermatid postacrosomal membrane (fig. 5). 
In some defective cells the membranous fube previously described (see paragraph b) was only linked to the postnuclear band (fig. 4) or to the perinuclear ring (fig. 5). The tube and postnuclear band had then slipped backwards along the nuclear envelope to reach a normal distal position ar the end of step 12 . The perinuclear ring and the manchette remained in equatorial position where they could still be observed in mid-step 13 (fig. 5). The perinuclear substance and the postacrosomal lamina appeared normally in the cytoplasm.

\section{Discussion.}

As already seen with more sophisticated techniques (Courtens and Loir, 1975a), the differentiation of the postacrosomal cytoplasm of the ram spermatid takes place during stage 12 of spermiogenesis, following nuclear loss of lysine-rich proteins (Courtens and Loir, 1975b). Nevertheless, as every organelle present in this region is modified simultaneously or slips backwards as if responding to a wave in both the nucleus and cytoplasm, it appears difficult to distinguish which organelle, if any, plays a molor role in spermatid differentiation. Moreover, the adjacent specialized mantle of the Sertoli cell displays a pattern of modifications similar to that of the spermatids (Courtens and Loir, 1975b).

The present observations of a small number of defective step 12 spermatids in $\mathrm{H}^{-}+$testosterone rams indicate that endocrine conditions do not seem to be directly involved in this abnormal cell differentiation since most of the oldest spermatids are normal in appearance.

The constant association of the plasma membrane with both the postnuclear band and the perinuclear ring in normal spermatids, and the general association of a membranous tore with these same two organelles in defective spermatids, suggest that the membranous tore we observed is a part of the plasma membrane. This supposedly broken and rearranged part of the plasma membrane displays a great affinity for the two organelles. The backward migration of the posinuclear band - membranous tube - perinuclear ring unit along a modifying nuclear envelope facing the nucleus, whose contents are also being modified (Courtens and Loir, 1975a), suggests that the most important events in the differentiation of the postacrosomal cytoplasm may be (i) the nuclear loss of lysine-rich proteins, (ii) modifications in the structure (Sandoz, 1974) or composition (Courtens and Loir, 1975) of the nuclear membrane, or (iii) backward displacement of the postnuclear band. Among these three events, modification of the nuclear content should be considered as the main factor influencing the morphogenesis of cytoplasmic organelles since Bacetti ef al. (1977) observed abnormal lysine content in the nuclei of human spermatozoa and a cytoplasm devoid of specialized postacrosomal cytoplasm.

Moreover, our observations clearly show that the perinuclear ring supporting the manchette (Rattner and Brinkley, 1972) migrates backwards only when attached to the postnuclear band by a portion of membrane.

Thus, the morphogenetic role hypothetically played by the perinuclear ring (Fawcett et al., 1971 ; Dym and Cavicchia, 1978) may be largely assigned to the postnuclear band. This band lying between the nuclear envelope and the plasma membrane effectively separates the spermatid cytoplasm into two parts, the head cyto- 
plasm and the posterior cytoplasm. According to our observations of postacrosomal cytoplasm morphogenesis, at least one of the roles of the postnuclear band in normal spermatids would be to place the plasma membrane close against the postacrosomal dense lamina. This action may be facilitated by the development and the close apposition of the Sertoli mantle against the spermatid plasma membrane since actin-like molecules have been recently evidenced in this Sertoli organelle (Toyama, 1975). Whatever may be the forces acting on the spermatid plasma membrane, it appears that the postacrosomal lamina, which was previously considered as a differentiation of the inner leaflet of the plasma membrane (Fawcett, 1970), is in fact a cytoplasmic organelle. Its appearance, as well as that of the perinuclear substance, occur in a cytoplasmic region devoid of any endoplasmic reticulum and separated from the ribosome-rich cytoplasm fraction (mainly the posterior cytoplasm : Dym and Cavicchia, 1978) by the postnuclear band. This apparition would reflect the morphogenetic organization of previously synthesized protein molecules.

In conclusion, the main factors influencing postacrosomal cytoplasm morphogenesis seem to be modifications of the spermatid nuclear content as well as changes in structure, composition and position of the nuclear envelope. The postnuclear band which slips backwards along the modifying nuclear envelope causes the plasma membrane to be closely apposed on the postacrosomal lamina, and forces the perinuclear ring and its associated manchette backwards.

Reçu en mai 1978.

Accepté en oout 1978.

Acknowledgements. - We thank Dr M. Courot and Dr M. Loir for critical reading of the manuscript. The technical assistance of $\mathrm{MrM}$. Teriot is gratefully acknowledged.

Résumé. L'étude ultrastructurale des spermatides au stade 12 chez le bélier normal, ou le bélier hypophysectomisé supplémenté en testostérone pendant 15 ou 20 jours, permef de montrer que la morphogenèse du cytoplasme postacrosomique suit, dans le temps et dans l'espace, les modifications de la composition du noyau en nucléoprotéines. Celles-ci sont suivies par des altérations de la structure de l'enveloppe nucléaire et un glissement vers l'arrière des anneaux péri et postnucléaires. L'anneau postnucléaire joue un rôle morphogénétique très important dans l'accolement de la membrane plasmique de la spermatide aux organites cytoplasmiques postacrosomiques.

\section{References}

BACETTI B., RENIERI T., ROSATI F., SELMI M. G., CASANOVA S., 1977. Further observations on the morphogenesis of the round headed spermatozoa. Andrologia, 9, 255-264.

BEDFORD J. M., 1974. Biology of primate spermatozoa. Contrib. Primatol., 3, 97-139.

BUSTOS-OBREGON E., COUROT M., FLÉCHON J. E., HOCHEREAU-DE-REVIERS M. T., HOLSTEIN A. F., 1975. Morphological appraisal of gametogenesis spermatogenetic process in mammals with particular reference to man. Andrologia, 7, 141-163.

CLERMONT Y., LEBLOND C. P., 1955. Spermiogenesis of man, monkey, ram and other mammals as shown by the "periodic acid-Schiff " technique. Am. J. Anat., 96, 229-253.

COURTENS J. L., LOIR M., 1975a. Mise en évidence par cytochimie ulłrastructurale de la migration des histones riches en lysine au cours de la spermiogenèse du bélier. J. Microscopie, 24, 249-258. 
COURTENS J. L., LOIR M., 1975b. Mise en évidence par cytochimie ultrastructurale de l'évolution des organites cytoplasmiques de la spermatide du bélier contemporaine de la perte des histones somatiques. J. Microscopie, 24, 259-270.

COURTENS J. L., 1978. Cytochimie ultrastructurale de la spermiogenèse du bélier. Introduction à l'étude de quelques facteurs déterminant la différenciation des structures de la tête du spermatozoïde. Thes. Univ. Paris VI.

DYM M., CAVICCHIA J. C., 1978. Functional morphology of the testis. Biol. Reprod., 18, 1-15.

FAWCETT D. W., 1970. A comparative view of sperm ultrastructure. Biol. Reprod., suppl. 2, 90-127.

FAWCETT D. W., ANDERSON W. A., PHILIPS D. M., 1971. Morphogenetic factors influencing the shape of the sperm head. Dev. Biol., 26, 220-251.

FLÉCHON J. E., 1975. The head of epididymal and ejaculated spermatozoa (rabbit), 68-81. In HAFEZ E. S. E. Scanning electron microscope atlas of mammalian reproduction. Igaku Skoin, Tokyo.

FRANKLIN L. E., BARROS C., FUSSELL E. N., 1970. The acrosomal region and acrosome reaction in sperm of the golden hamster. Biol. Reprod., 3, 180-200.

GORDON M., 1972. Observations on the postacrosomal region and the neck membranes of rabbit spermatozoa stained in bloc with uranyl acetate. Z. Zellforsch. Mikrosk. Anat., 131, 15-25.

JONES R. C., 1971. Studies of the ultrastructure of the head of some mammalian spermatozoa with particular reference to the perforatorium. In FAVARD P. 7th Congr. int. Micros. electr., 3, 641-642.

JONES R. C., 1971. Studies of the structure of the head of boar spermatozoa from the epididymis. J. Reprod. Fertil., suppl. 13, 51-64.

LALLI M. F., 1972. The head of the rat spermatozoa and its formation during spermiogenesis : an electron microscopic study. Diss. Abs., 33, 2900.

MONET-KUNTZ C., TERQUI M., LOCATELLI A., HOCHEREAU-DE-REVIERS M. T., COUROT M., 1976. Effet de la supplémentation en testostérone sur la spermatogenèse de béliers hypophysectomisés. C. R. Acad. Sci. Paris, sér. D, 283, 1763-1766.

RATTNER J. B., BRINKLEY B. R., 1972. Ultrastructure of mammalian spermiogenesis. III. The organization and morphogenesis of the manchette during rodent spermiogenesis. J. Ulirast. Res., 41, 209-218.

SANDOZ D., 1970. Evolution des ultrastructures au cours de la formation de l'acrosome du spermatozoïde chez la souris. J. Microscopie, 9, 535-558.

SANDOZ D., 1974. Modifications in the nuclear envelope during spermiogenesis of discoglossus pictus (Anuran amphibia). J. Submicr. Cytol., 6, 339-419.

TOYAMA Y., 1975. Actin like filaments in peritubular myoid and Sertoli cell of the swine and mouse testis 10 th int. Congr. Anat., Tokyo, 443. 